\title{
Techniques for the Isolation of Magnetotactic Bacteria
}

Nimali N Prabhu* and Meenal Kowshik

Department of Biological Sciences, BITS-Pilani, KK Birla Goa Campus, Goa, India

\begin{abstract}
Magnetotactic bacteria (MTB), a diverse group of ubiquitously occurring Gram negative procaryotes are currently the subject of interdisciplinary research. The unique trait of synthesis and biomineralization of nano-sized magnetic particles in the ideal range of 30 to $120 \mathrm{~nm}$ makes them suitable for biomedical and biotechnological applications. However, research in this field has not reached a commercial scale as these bacteria are notoriously difficult to culture. Culturing this metabolically versatile group of bacteria on defined medium is still a challenging task even though a few MTB strains have been isolated and purified in the past. Scientists worldwide are developing different strategies to trap MTB under artificial laboratory conditions. This review summarizes various apparatus, setups and media formulations designed for obtaining axenic MTB strains since their discovery by Richard Blakemore in 1975.
\end{abstract}

Keywords: MTB; Magnetic field; Magnetosomes; Isolation method; Magnetite crystals

\section{Introduction}

It has been forty years since Richard Blakemore discovered "Magnetotactic bacteria (MTB)" [1]. These microorganisms have the capability to positively respond and swim in the direction of external magnetic field. This response is due to their innate mechanism of biosynthesis of nano-sized magnetic particles inside the cells. These nanomagnets make the cells act or behave like tiny, self-propelled compass needles, aligning the bacteria to external magnetic field. Each nanocrystal is encapsulated by an organic membrane and called 'magnetosome' $[1,2]$. The mineral form of the crystal is composed of either iron oxide $\left(\mathrm{Fe}_{3} \mathrm{O}_{4}\right)$ i.e. magnetite or iron sulfide $\left(\mathrm{Fe}_{3} \mathrm{~S}_{4}\right)$ i.e. greigite [3-12]. Bacterial magnetosomes range from 30 to120 nm in size $[5,13]$. This size range is ideal for a large number of biomedical and other biotechnological applications. The unique trait of biosynthesis of magnetosomes, has made MTB a subject for interdisciplinary research. However, research in this field is limited and has not progressed to a commercial level due to the fastidious and diverse metabolism of magnetotactic bacteria [14]. It is difficult to cultivate MTB under the artificial laboratory environment [14-16] and various methods are being developed for obtaining pure MTB strains. This review aims to summarize methods that have been designed for the isolation of MTB, techniques used to trap these bacteria and scale up its production as well as enrichment media designed to mimic the natural environment such that it is favorable for their growth. Currently, there are very few axenic strains of MTB and more number of pure cultures are required inorder to understand the mechanism of biomineralization. Therefore this review emphasizes on the need for the isolation and studying MTB from diverse environments.

\section{Magnetotactic bacteria and magnetosomes}

'Magnetotactic Bacteria' are metabolically diverse Gram negative prokaryotes that swim in the direction of external magnetic field. This swimming behavior is referred to as "magnetotaxis" [1,5]. In the northern hemisphere, MTB swim towards the south pole of a magnet and viceversa is true in the southern hemisphere and either ways at the geomagnetic equator [2]. MTB are fast moving organisms and their movement is due to the presence of flagella $[5,14]$. Magnetotaxis is an important phenomenon in these bacteria as they are microaerophilc, facultatively microaerophilic or obligately anaerobic in nature. They are therefore found in abundance at the oxic-anoxic transition zone (OATZ) and prefer to grow at low oxygen concentrations prevailing in their natural habitats [17-22]. Magnetotaxis along with aerotaxis and chemotaxis help these organisms find an ideal micro-oxic condition in the chemically stratified natural environs [23].

Based on the morphology and physiology, magnetotactic bacteria are grouped under different phyla [24]. All the MTB so far reported belong to the domain Bacteria. They are polyphyletic and span over five distinct phyla namely; Alphaproteobacteria, Deltaproteobacteria, Gammaproteobacteria, Nitrospira and the candidate division OP3, part of the Planctomycetes-Verrucomicrobia-Chlamydiae (PVC) bacterial superphylum [24-26].However, irrespective of theirphylogeneticlineage, all of them possess multiple magnetic nanoparticles [14]. Synthesis of magnetic nanoparticles occurs under controlled biomineralization and results in perfectly shaped ferrimagnetic crystals of magnetite or greigite. The cells systematically organize these membrane-enveloped crystals into highly ordered chains. Magnetosomes vary in size and range between 30 to $120 \mathrm{~nm}$ which is the ideal size for magnetotaxis. These intracellular crystals possess stable single magnetic domain and are permanently magnetic in nature [3-14]. Depending upon the species, these chains may vary in morphology, size, composition as well as arrangements. However, uniform crystals are synthesized within a single species. A cell may synthesize one or multiple chains and it is these chains that are responsible for the resulting magnetotactic response of the bacterium [5,14]. Since magnetite crystal formation is essentially controlled by low oxygen concentration, MTB cells travel in search of microaerophilic habitats whereas greigite formation occurs under oxygen free conditions. The highest numbers of MTB are reported close to the oxic-anoxic transition zone [15-21]. MTB are found ubiquitously in diverse ecological habitats from aquatic (marine and freshwaters), to deep sea sediments, salt marshes, wet soils, hot springs and even in extremely cold regions [22-26]. Their diversity in terms of morphology, physiology and phylogeny is outstanding. The morphological types include cocci, bacilli, vibrios, spirilla, ovoid, giant

*Corresponding author: Nimali N Prabhu, Department of Biological Sciences, BITS-Pilani, KK Birla Goa Campus, Goa, India, Tel: 0832258 0101; E-mail: nimalidhond@gmail.com

Received February 16, 2016; Accepted March 01, 2016; Published April 08, 2016

Citation: Prabhu NN, Kowshik M (2016) Techniques for the Isolation of Magnetotactic Bacteria. J Microb Biochem Technol 8: 188-194. doi: 10.4172/19485948.1000284

Copyright: () 2016 Prabhu NN, et al. This is an open-access article distributed under the terms of the Creative Commons Attribution License, which permits unrestricted use, distribution, and reproduction in any medium, provided the original author and source are credited. 
Citation: Prabhu NN, Kowshik M (2016) Techniques for the Isolation of Magnetotactic Bacteria. J Microb Biochem Technol 8: 188-194. doi: 10.4172/1948-5948.1000284

and multicellular MTB [27-37]. However, this large morphological diversity can only be visualized microscopically and not in culture. R. Blakemore was the first to isolate MTB as an axenic laboratory strain and named it Aquaspirillum magnetotacticum MS-1 [38]. Subsequently, other species closely related to Aquaspirillum (Magnetospirillum) magnetotacticum MS-1, were isolated (Table 1). Cultured MTB strains include Magnetospirillum gryphiswaldense MSR-1 [39,40], Magnetospirillum magnetotacticum AMB-1 [41,42], Magnetospirillum magneticum MG-T1 [43], Magnetovibrio MV-1 [44] and MV-2 [45], marine spirillum strain MMS-1[45], Magnetococcus sp. MC-1 [46], marine magnetic spirillum QH-2 [37] and Magnetospirillum sp. WM-1 [47]. All the above cultured isolates are mesophilic with respect to $\mathrm{pH}$ and temperature, synthesize intracellular magnetite crystals and belong to Alphaproteobacteria [14,16-18]. Desulfovibrio magneticus strain RS-1 is the only cultured anaerobic, sulphate reducing, magnetite forming rod affiliated to the genus Desulfovibrio of Deltaproteobacteria [47-49]. The uncultured greigite forming "multicelled magnetic prokaryote" (MMP) was detected in marine environment and found to be related to the dissimilatory sulphate reducing bacteria of the Deltaproteobacteria [50]. A 'barbell' shaped bacterium from a marine sulphidic pond is associated with the genus Desulforhopalus [51]. Magnetotactic bacteria affiliated to Gammaproteobacteria have also been reported [33]. Uncultured MTB also belong to other phyla. An unusually large rod shaped bacterium with five magnetite chains, each containing approximately 200 particles (i.e. nearly 1000 magnetosome particles per cell) was isolated from different microcosm sediments. This strain designated 'Candidatus Magnetobacterium bavaricum' was found to share $91 \%$ sequence homology with a freshwater bacterium 'Candidatus Magnetobacterium bremense' (MHB-1) and both belonged to the phylum Nitrospira [52]. Another unusual MTB type was reported from the Pettaquamscutt river that could coprecipitate both magnetite and greigite in the cells [7].
Report on the isolation and axenic culture of three obligately alkaliphilic, anaerobic, sulphate-reducing MTB has been published. These isolates ML-1, ZZ-1 and AV-1 were obtained from three different sites namely; Mono Lake, Soda Spring and a small pond at Armagosa Valley respectively. Mono Lake is a hyperalkaline and hypersaline lake ( $\mathrm{pH} 9.8$ and salinity 68 parts per thousand (ppt) near the sampling site). The high sodium and carbonate concentrations arise from weathering of the volcanic rocks and hydrothermal inflow into the lake water. The alkaline Soda Spring ( $\mathrm{pH} 9.5$ \& salinity $~ 27 \mathrm{ppt}$ ) and the seasonal alkaline pond ( $\mathrm{pH} 9.5 \&$ salinity $3 \mathrm{ppt}$ ) have low salinities compared to Mono Lake. The water from these econiches is found to be iron limited due to low solubility of iron at high $\mathrm{pH}$. The mud and water samples collected from all the three locations revealed MTB of a single morphotype containing bullet-shaped magnetite magnetosomes upon microscopic examination [53]. Piezotolerent MTB in hemipelagic and pelagic sediments as well as facultatively psychrophilic MTB strains in lake samples were detected in other studies [54].

Acidophilic MTB have not been reported from acid mine drainages or other acidic environs though iron is more soluble and hence available for biomineralization under these conditions. However, extraction and purification of magnetite crystals have been demonstrated in strain Leptospirillum ferriphilum YSK isolated from acid mine drainage. This strain is morphologically and metabolically similar to MTB $[55,56]$.

So far, only one report on the isolation of an MTB strain, designated SS-5 isolated in pure culture from hypersaline Salton Sea (salinity 50 ppt) is available. However, it does not exhibit requirement of high salt for growth as also observed in case of strain ML-1 isolated from Mono Lake (salinity $68 \mathrm{ppt}$ ). Halophilic strains and MTB possess similar pattern of metabolism (dissimilatory sulfate reduction) and therefore it can be a possibility to find halophilic MTB in hypersaline environments [26,57].

\begin{tabular}{|c|c|c|c|c|}
\hline Strain & Location & Sample type & Phylum & Isolated by \\
\hline $\begin{array}{l}\text { Magnetospirillum } \\
\text { magnetotacticum strain } \\
\text { MS-1 }\end{array}$ & $\begin{array}{c}\text { Woods Hole, Massachusetts, } \\
\text { USA }\end{array}$ & $\begin{array}{l}\text { Mud and water from Cedar } \\
\text { swamp }\end{array}$ & Alphaproteobacteria & Blakemore et al. [38] \\
\hline $\begin{array}{l}\text { Magnetovibrio blakemorei } \\
\text { strain MV-1 }\end{array}$ & Boston, Massachusetts, USA & $\begin{array}{l}\text { Sulphidic sediments from } \\
\text { estuarine salt marsh }\end{array}$ & Alphaproteobacteria & Bazylinski et al. [44] \\
\hline $\begin{array}{c}\text { Magnetospirillum } \\
\text { magneticum strain MG-T1 }\end{array}$ & Tokyo, Japan & Aerobic sediments from ponds & Alphaproteobacteria & Matsunaga et al. [43] \\
\hline $\begin{array}{l}\text { Magnetospirillum } \\
\text { magnetotacticum strain } \\
\text { AMB-1 }\end{array}$ & Koganei, Tokyo, Japan & $\begin{array}{c}\text { Freshwater sludges and pond } \\
\text { sediments }\end{array}$ & Alphaproteobacteria & Matsunaga et al. [41] \\
\hline $\begin{array}{c}\text { Magnetospirillum } \\
\text { gryphiswaldense strain } \\
\text { MSR-1 }\end{array}$ & Greifswald, Germany & Mud from eutrophic Ryck river & Alphaproteobacteria & Schuler and Kohler [39] \\
\hline $\begin{array}{l}\text { Magnetococcus marinus } \\
\text { strain MC-1 }\end{array}$ & Rhode Island, USA & $\begin{array}{l}\text { Water from Pettaquamscutt } \\
\text { estuary }\end{array}$ & Alphaproteobacteria & Meldrum et al. [46] \\
\hline $\begin{array}{l}\text { Magnetovibrio sp. strain } \\
\text { MV-2 }\end{array}$ & Rhode Island, USA & $\begin{array}{l}\text { Water from Pettaquamscutt } \\
\text { estuary }\end{array}$ & Alphaproteobacteria & Meldrum et al. [45] \\
\hline $\begin{array}{l}\text { Magnetospira thiophila strain } \\
\text { MMS-1 (MV-4) }\end{array}$ & Woods Hole, Massachusetts, USA & $\begin{array}{c}\text { Mud and water from School } \\
\text { Street Marsh }\end{array}$ & Alphaproteobacteria & Meldrum et al. [45] \\
\hline $\begin{array}{l}\text { Desulfovibrio magneticus } \\
\text { strain RS-1 }\end{array}$ & Western Japan & $\begin{array}{c}\text { Water and Sulphide rich } \\
\text { sediments from water way } \\
\text { near Kameno river }\end{array}$ & Deltaproteobacteria & Sakaguchi et al. [48] \\
\hline Magnetospirillum sp. WM-1 & Qingshan, Wuhan, China & $\begin{array}{l}\text { Fresh water and sediment } \\
\text { from North Lake }\end{array}$ & Alphaproteobacteria & Li et al. [47] \\
\hline $\begin{array}{c}\text { unidentified strains MG-1 \& } \\
\text { MG-2 }\end{array}$ & $\begin{array}{c}\text { Qingyang, Gansu Province \& } \\
\text { Nanjing, China }\end{array}$ & $\begin{array}{l}\text { Paleosol layer with high } \\
\text { magnetic susceptibility \& } \\
\text { Fresh water pond sample }\end{array}$ & $\begin{array}{l}\text { Gammaproteobacteria \& } \\
\text { Cyanobacteria, respectively }\end{array}$ & Xiao et al. [71] \\
\hline $\begin{array}{l}\text { Magneto-ovoid bacterium } \\
\text { MO-1 }\end{array}$ & Marseille, France & $\begin{array}{l}\text { sediment water interface } \\
\text { Sample in Pionte Rouge }\end{array}$ & Alphaproteobacteria & Lefevre et al. [59] \\
\hline $\begin{array}{c}\text { Marine magnetic spirillum } \\
\text { QH-2 }\end{array}$ & Qingdao, China & $\begin{array}{c}\text { Seawater pond sample at } \\
\text { Huiquan Bay }\end{array}$ & Alphaproteobacteria & Zhu et al. [37] \\
\hline
\end{tabular}

Table 1: List of Cultured Mesophilic Magnetotactic Bacterial Strains. 
As of now there are no reports available on cultured greigite producing MTB and very few cultured magnetite producers are reported [58]. MTB can be differentiated from other bacteria based on its swimming ability towards natural or artificially applied magnetic field. For them, it is a survival strategy to move away from unwanted environs to more growth-favoring once [2,16-18]. This swimming ability has been exploited by researchers worldwide to tape as yet uncultivated strains of MTB from diverse econiches. It provides an advantage to isolate, enrich and purify them. However, the difficulty lies in the culture of the wild type MTB on synthetically defined medium as they are fastidious in nature [14]. Their versatile metabolism is still not known and hence reproducing the wild type in culture has become a challenging task. This review describes the techniques used and the recent advances in design of special setups and media formulations for isolation and cultivation of MTBs under laboratory conditions.

\section{Isolation techniques used since MTB discovery}

Richard Blakemore's work has given a new dimension to MTB research. He observed a bacterium which exhibited a magnetotactic response [1]. A simple technique of incubating mud samples overlayed with sea water in glass jars under dim light was employed. Upon storage over a period of time, the samples underwent ecological succession. MTB in the samples increased several hundreds of thousands of cells per milliliter $(\mathrm{ml})$ in many mud samples. MTB from the enriched mud samples were then separated based on their magnetotactic response. A few sea water drops were placed in contact with the MTB enriched mud sample drops on a microscopic slide. Fast moving MTB from the northern edge of the enriched sample travelled to the seawater drops which were collected using a micropipette. On examination under electron microscope, magnetotactic, spherical, flagellated cells were observed. These cells contained two chains, each of five to ten electron dense intracellular membrane-bound magnetite crystals. Energy dispersive $\mathrm{X}$-ray (EDAX) microanalysis of the magnetite chains within a single cell revealed that these crystals composed mainly of iron. In subsequent work, Blakemore and coworkers isolated a freshwater bacterium, Aquaspirillum magnetotacticum strain MS-1 in pure culture [38]. This microaerophilic, heterotrophic spirillum was cultured in a chemically defined medium. Jars were filled with mud and water upto two third of their volume and loosely covered. These were then left undisturbed at R.T. for one or more months. After incubation, a small amount of this diluted sample was used to inoculate vials containing one sixth their volume with test medium. Vials were sealed and replaced with the test gas. MTB growth was then determined by microscopic counts of motile magnetic cells. For isolation of strain MS1 , inoculated tubes were incubated at room temperature (R.T.) in dark. After growth of the culture, cells were diluted serially into molten tubes of pre-reduced isolation medium containing $0.85 \%$ agar. Pure isolated colonies of strain MS-1 were obtained and maintained at $30^{\circ} \mathrm{C}$ with weekly subculture in screw capped tubes containing semisolid growth medium.

Development of an enrichment method to grow MTB under laboratory conditions was achieved by Moench and Konetzka [58]. Their work involved duplication of small sewage oxidation ponds where these bacteria would proliferate as in their natural microcosm. Cultivation of MTB in the laboratory was done by layering fresh oxidation mud in beakers or battery jars. Addition of secondary influent and duckweed (Lemnasp.) from a pond was carried out. Jars were covered to prevent evaporation and incubated under subdued sunlight on the window sill at 20 to $27^{\circ} \mathrm{C}$. After one to two months of incubation, large numbers of magnetococci were observed. These were collected using magnets. The south pole of both stirring bar magnets was placed on the opposite sides of the jar, exactly at the midpoint between the sediment water interface and the water surface using clay support for 30 minutes (Figure 1). The MTB accumulated near the magnet were removed using a Pasteur pipette and used for further analysis. Presence of MTB in other aquatic sediments was also determined. In this case the south magnetic pole of the stirring bar was kept perpendicular to the glasswall of the collection bottle such that the magnetic focus was at the sediment level. The bacteria that migrated to the focus were procured using Pasteur pipette after 30 to 60 minutes. The sample was then examined using phase contrast microscopy. Magnetotactic bacteria were found to be highly motile and refractile and exhibited clumping under the application of magnetic field.

Other reports on the isolation of MTB involving incubation and enrichment of the microcosm samples include isolation of Magnetospirillum gryphiswaldense strain MSR-1, a magnetotactic spirillum cultivated axenically by Schuler and Kohler [39]. In this study, mud from an eutrophic river was incubated microaerobically for enrichment of MTB. After magnetic separation and growth in the isolation medium, the cell suspension containing homogeneous populations of magnetic spirilla were purified. Isolation of Mediterranean MTB also involved collection of interface water and sediment and magnetic enrichment. In this study, brown-black spots of MTB were observed near the south magnetic pole. MTB were then withdrawn and characterized using optical and electron microscopy. Diverse morphological types including cocci, rods, vibrios, spirilla and multicellular MTB were present. When cultured after racetrack enrichment, a magneto-ovoid strain was obtained. This strain designated MO- 1 contained only one chain of magnetite magnetosomes in single domain range [59]. An axenic culture was also obtained by Zhu and coworkers from a seawater pond [37]. This strain $\mathrm{QH}-2$ was isolated using magnetic enrichment and purification. It was phylogenetically affiliated to Alphaproteobacteria. The intracellular magnetosomes contained iron oxide mineral as revealed by EDAX and electron diffraction.

A more routinely used 'Capillary racetrack' (CRT) method for MTB isolation and purification makes use of a Pasteur pipette sealed at one end [60]. An absorbent cotton plug is packed very loosely into the narrow neck of the capillary tube and the pipette is sterilized. Through the wide-mouth of the pipette, sterile water is introduced using a syringe until the capillary is filled. Excess water above the cotton plug is withdrawn and the cotton is firmly packed into the neck of the capillary. MTB containing sediment is then placed in the reservoir of the pipette. The sealed end side of the capillary is inserted in the slide holder and placed on the microscope stage. It is then exposed to the south pole of a stirring bar magnet. Movement of the actively swimming MTB is monitored under phase contrast microscope. The motile MTB accumulating at the tip of the capillary are harvested by breaking off the tip after a few minutes. Finally the contents are retrieved using a sterile

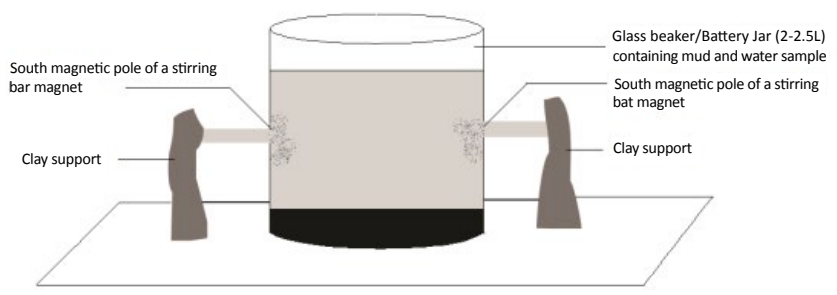

Figure 1: Magnetic collection of MTB [58] 
Pasteur pipette. This is used as MTB inoculum for further enrichment and purification studies (Figure 2).

Some scientists have made use of simple enrichment media for cultivation of MTB. A simple agar-mud medium for the enrichment and cultivation of MTB has been reported by Adamkiewicz et al. in 1991 [61]. This medium contained low concentrations of agar and pulverized sediment. The magnetically enriched MTB sample was introduced in test tubes containing the agar-mud medium and incubated for about 10 days at R.T. under dim light. After incubation, a white line was visible 2 to $3 \mathrm{~cm}$ below the surface of the medium. Upon microscopic examination, diverse morphologies of MTB such as cocci, spirilla, vibrios and rods were observed. Electron micrographs of the sample revealed presence of chains of magnetosomes inside the MTB cells.

Isolation of an aerobic rod shaped MTB strain YSC-1 from marine sediments was also achieved by colony formation on agar plates. Strain YSC-1 biomineralized intracellular magnetite magnetosomes [62]. Sharma et al. 2011 have isolated MTB using nutrient broth containing ferric quinate [63]. This oxygen tolerant strain was found to be south-seeking and contained magnetite crystals in the cell. Enhanced magnetosome yield has been observed when Magnetospirillum magneticum was cultured using ferrous sulphate, ferric gallate and to a slight extent by ferric quinate [64]. Uptake of iron into the cells is an energy-dependent and highly regulated process. The mechanism of biosynthesis of magnetite and magnetosome formation is not fully understood and a few hypothetical models have been proposed [16]. According to Jogler and Schuler, this process occurs by the uptake and transport of extracellular ferrous or ferric ions into the cell [65]. This unknown uptake system is coupled with magnetite biomineralization. The ferrous ions are transported by $\mathrm{MamB} / \mathrm{MamM}$-proteins either from the cytoplasm or the periplasmic space into the preformed intracellular vesicles. Intravesicular iron is then converted to magnetite with the help of protein such as MamT. Mechanism proposed by Arakaki et al. suggested formation of magnetosome-membrane invaginations originating from cytoplasmic membrane primed by GTPases [66]. Further, the synthesized vesicles formed a linear chain along with cytoskeletal filaments. Iron uptake from the external environment was found to be aided by transport proteins and low molecular weight iron chelators i.e. siderophores. Transmembrane iron transporters were involved with intravesicular iron accumulation. Additional magnetosome associated proteins were also found to play an important

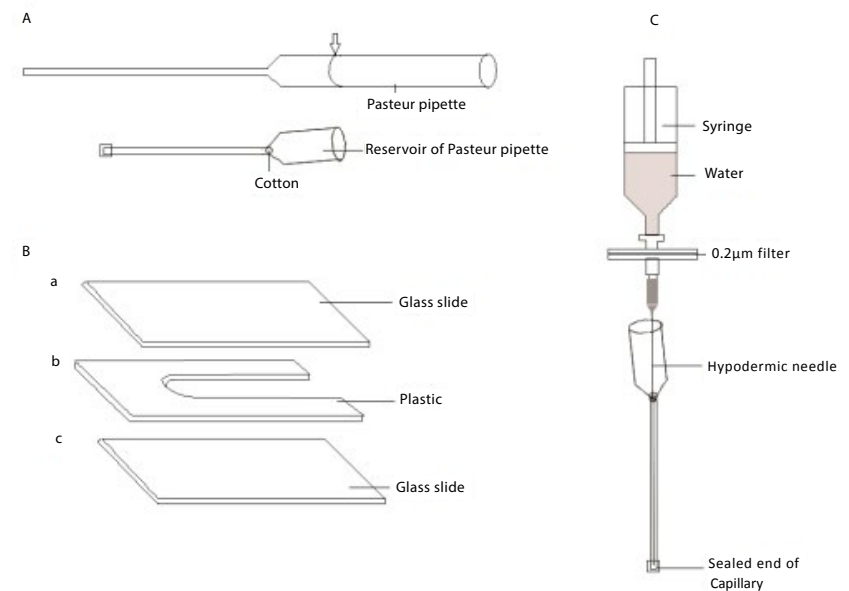

Figure 2: 'Capillary Racetrack' (CRT) Design for isolation and purification of MTB [60]. role in accumulation of iron to super-saturation level, maintaining the redox potential and regulating crystal structure and nucleation process [66].

Most of the methods used for the isolation and cultivation depend solely on the basis of active swimming behavior of MTB. This narrows down the possibility of obtaining weakly or non-magnetic strains of MTB present in the natural habitats. The isolation of a weakly magnetotactic sulfate reducing, rod shaped bacterium Desulfovibrio magneticus strain RS-1, without using external magnetic field was reported for the first time by Sakaguchi et al. in 1996 [48].The method was based on enrichment of MTB by incubating sediment and water in 1:2 proportions in glass bottles with loosely held plastic caps to allow gaseous exchange with the atmosphere. The bottles were incubated at R.T. and changes in the sample were observed. Incubated water and enrichment medium containing water sample were tested for the presence of MTB. For this, a samarium-cobalt (Sm-Co) magnet was placed near the glass slide on the stage of the microscope. Rotation of the cells in the sample enriched drop was monitored by rotating the direction of magnet. The cells were found to be magnetosensitive. The enrichment medium which contained potassium dihydrogen phosphate, ammonium nitrate, yeast extract, succinate, Wolfe's mineral solution without ferrous sulfate, sodium thioglycolate, and an iron source was then optimized with respect to iron, sulfur and nitrogen source. The ideal iron source was found to be ferric quinate $(32 \mu \mathrm{M})$. Sodium sulfate $(0.31 \mathrm{mM})$ was used as an electron acceptor and 0.3 $\mathrm{g} / \mathrm{L}$ yeast extract (carbon source) as an electron donor. Nitogen source in either nitrate or nitrite form had no effect and did not contribute to an increase in cell number. Inhibitory effect of nitrate on the synthesis of magnetic particles has been demonstrated by Matsunaga et al. [67]. In this study, increased nitrate concentration reduced magnetite production in Magnetospirillum magneticum indicating magnetite biosynthesis to be inhibited by reduction of nitrate to nitrogen in the medium.

Some of the research groups interested in studying MTB diversity in the natural microcosms have developed techniques to study their phylogenetic diversity. The phylogenetic diversity of MTB has been analyzed using two approaches: Racetrack-based and Metagenomebased PCR method. In the first approach, capillary racetrack method was used to enrich MTB from the targeted environmental sample. In the second approach, the metagenomic DNA from the extracted sediments was used. Three clusters of magnetic cocci were identified by metagenome-based PCR method. Capillary racetrack enrichment could detect only one of these suggesting that this method truly relies on the efficient magnetotaxis of the organism. Therefore it was obvious that metagenome-based method is more reliable and unbiased in revealing the true diversity of uncultivated MTB from any econiche [68]. In another study, Lin et al. 2009 have screened 16S rRNA gene library of enriched MTB from environmental samples using Restriction Fragment Length Polymorphism (RFLP) [69]. RFLP is a cultureindependent method and can be used to investigate the community structure of MTB. In this study, the resolving power of different sets of restriction endonucleases was assessed. The selected set of restriction endonucleases was then used to evaluate the diversity of MTB enriched sediment samples.

Different strategies to isolate MTB either in culture or uncultivable form to study their diversity have been used by developing simple homemade apparatus. Matsunaga and Kamiya, [70] designed one of the first apparatus for harvesting MTB (Figure 3). Using the modified form of this isolation apparatus and capillary racetrack method described by Wolfe et al. 1987, a new strain of MTB was isolated [3] 
It was designated as Magnetospirillum magneticum strain MG-T1. This isolate was helical in shape and cultured at $25^{\circ} \mathrm{C}$ on agar medium under microaerobic conditions. Cells accumulated magnetite crystals and had oxidase activity. This oxygen tolerant strain could grow on a variety of different carbon and iron substrates [43]. Matsunaga et al. 1991 also isolated and cultured a helical shaped freshwater MTB strain that biomineralized magnetite magnetosomes in a chain [41]. A single chain consisted of 15 magnetite crystals of average $50 \mathrm{~nm}$ in diameter. This strain designated Magnetospirillum magnetotacticum AMB-1 was found to be oxygen tolerant and positive for oxidase. Cells produced magnetite under aerobic conditions in liquid cultures that were shaken at $60 \mathrm{rpm}$ for $120 \mathrm{~h}$. Sodium nitrate was found to be the best nitrogen source for growth and magnetite formation in isolate AMB-1 [41]. An easy and inexpensive apparatus to isolate MTB in pure culture was also designed by Xiao and coworkers. By this method, they isolated oxygentolerant strains containing 3 to 8 intracellular magnetic particles $80 \mathrm{~nm}$ in size. Strain MG-1 is a rod shaped bacterium closely related to an uncultivated isolate SP_A2 and both belonged to Gammaproteobacteria whereas strain MG-2 was assigned to the phylum Cyanobacteria [71].

Studies on the isolation and identification of MTB from incubated mud and water samples were carried out using a special set-up by Farzan et al. 2010 (Figure 4) [72]. MTB that accumulated under the magnet were withdrawn using a pipette and inoculated on solid medium. Oxygen was replaced by a stream of nitrogen and the agar plates were sealed. The colonies obtained on the agar plates were transferred into liquid medium for enrichment of the magnetic bacteria. Results indicated presence of Gram negative, rod shaped isolates containing intracellular magnetic particles. TEM revealed these particles to range between 10 to $20 \mathrm{~nm}$ in size. From optical microscopic studies, the isolates were found to be both North- and South-seeking confirming their magnetic sensitivity. Alternating gradient force magnetometer (AGFM) analysis characterized the extracted magnetosomes to be superparamagneticto-single-domain behavior [72].

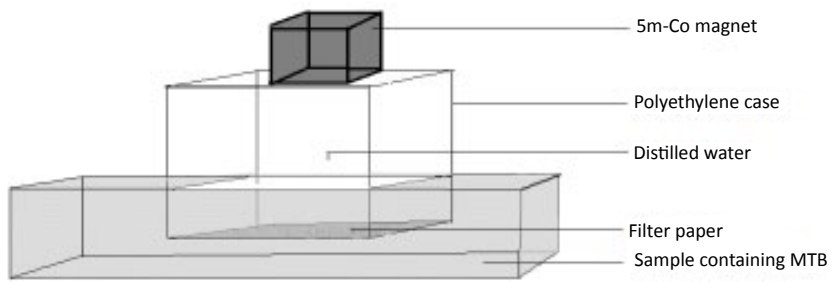

Figure 3: Magnetic enrichment of MTB using Samarium-Cobalt Magnet [70].

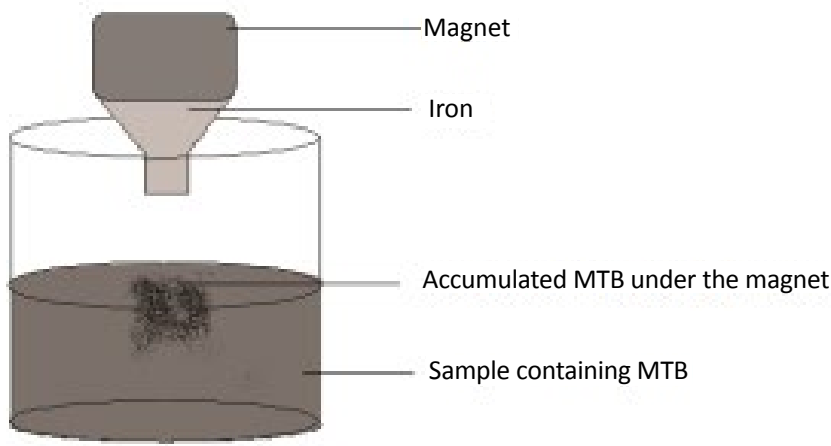

Figure 4: Isolation of MTB using a simple Magnet [72].
Diverse econiches such as Great Boiling Springs (GBS) in Nevada were also sampled for the examination of thermophilic MTB [55]. Presence of small, Gram negative, vibrioid to helicoid cells with single polar flagellum was observed. All the samples from nine springs revealed only one morphotype of MTB. Cells were found to be motile and viable over a temperature range from 25 to $62^{\circ} \mathrm{C}$. This uncultivated strain designated HSMV-1 and phylogenetically named 'Candidatus Thermomagnetovibrio paiutensis' belonged to the phylum Nitrospira. Strain HSMV-1 biomineralized a chain of average 15 magnetosomes containing bullet shaped magnetite crystals in single magnetic domain size range. Presence of MTB in the highly saline and alkaline Lonar lake of Maharashtra, India has also been reported [73]. MTB were isolated from these water samples after magnetic collection, modified capillary racetrack enrichment and purification. They were tested for magnetic response using hanging drop technique and also in terms of spreading of growth on $0.8 \%$ agar containing semi-solid medium. Among the different isolates obtained, one Gram negative, slender rod shaped bacterium exhibited strong response to the south pole of the magnet and contained 11.5 times more iron in the cells as compared to the nonmagnetic control.

Large scale production of magnetosomes is important for commercial applications. Some of the research groups specifically study the growth of MTB in order to scale up their yield. Kundu and Kulkarni, 2009 have reported an increased yield of strain MS-1 when grown in modified MSGM supplemented with 25\% nutrient broth. Strain MS-1 grew about five fold higher than that in normal MSGM under laboratory conditions. Moreover, the morphology as well as the characteristics of magnetosomes remained unchanged during growth in the modified MSGM [74].

A curved shaped MTB has been isolated and cultured successfully in liquid medium by Tajer-Mohammad-Ghazvini and coworkers [75]. The magnetosomes produced by this bacterium contained magnetite in a chain. The size of the magnetosomes ranged between 50 to 60 $\mathrm{nm}$. This falls in the single-magnetic-domain range that is ideal for biomedical and biotechnological applications. In this report the authors have described a scale-up strategy that can be used for large scale production of the bacterium employing air-tight laboratory bottles with aspiration system. The MTB strain was cultured under microaerobic conditions at R.T. The cells were harvested and magnetosomes were isolated, magnetically purified and used for further characterization. Karande et al. have also reported on the isolation and characterization of MTB synthesizing magnetic nanoparticles [76]. In this study, the soil samples were collected from iron ore mine in South Goa. The magnetic measurements of the soil samples were carried out using Molspin Vibrating Sample Magnetometer (VSM). The mid-layer soil sample exhibited higher magnetism and therefore was used for MTB enrichment. Enrichment samples contained rod shaped cells possessing magnetite magnetosomes as revealed by TEM micrographs. These authors have highlighted the importance of biosynthesized magnetic nanoparticles for biomedical applications such as magnetic hyperthermia used in cancer treatment [76].

\section{Conclusions and Future Prospects}

This review mainly summarizes different strategies used by researchers around the world to isolate and culture MTB axenically. Since MTB is cosmopolitan in nature and ubiquitously present in varied ecosystems, it gives an opportunity to study different aspects of MTB, with emphasis on its fastidious metabolism. In addition to its highly complex metabolism unknown till date, its oxygen requirement is also variable. Studies on magneto-aerotaxis reveal an efficient mode 
Citation: Prabhu NN, Kowshik M (2016) Techniques for the Isolation of Magnetotactic Bacteria. J Microb Biochem Technol 8: 188-194. doi: 10.4172/1948-5948.1000284

of survival in a chemically stratified environ and near OATZ. To mimic these conditions in the laboratory and culture MTB axenically is in itself a challenge. It is just the preliminary step towards optimization and large-scale production of these bacteria and in turn magnetosomes for commercial use. So far there are limited groups of scientists completely involved in MTB research. Though MTB diversity can be studied using molecular approaches without the need for cultivation, they are still interested in culturing wild type MTB strains. However, lack of knowledge on the physiology and versatile metabolism has hampered the study of this group of bacteria.

\section{Acknowledgement}

The author would like to thank SERB, DST, India (Grant No: SR/FT/LS120/2011) for the financial assistance.

\section{References}

1. Blakemore R (1975) Magnetotactic bacteria. Science 190: 377-379.

2. Lefèvre CT, Abreu F, Lins U, Bazylinski DA (2011) A bacterial backbone: magnetosomes in magnetotactic bacteria. Springer 15: 75-102.

3. Frankel RB, Blakemore RP, Wolfe RS (1979) Magnetite in freshwater magnetotactic bacteria. Science 203: 1355-1356

4. Heywood BR, Bazylinski DA, Garratt-Reed A, Mann S, Frankel RB (1990) Controlled biosynthesis of greigite (Fe3S4) in magnetotactic bacteria. Naturwissenschaften 77: 536-538.

5. Bazylinski DA, Frankel RB (2004) Magnetosome formation in prokaryotes. Na Rev Microbiol 2: 217-230.

6. Rodgers FG, Blakemore RP, Blakemore NA, Frankel RB, Bazylinski DA, et al (1990) Intercellular structure in a manycelled magnetotactic prokaryote. Arch Microbiol 154: 18-22.

7. Bazylinski DA, Heywood BR, Mann S, Frankel RB (1993) Fe3O4 and Fe3S4 in a bacterium. Nature 366: 218

8. Moskowitz BM, Frankel RB, Bazylinski DA (1993) Rock magnetic criteria for the detection of biogenic magnetite. Earth Planet Sci Lett 120: 283-300.

9. Lins U, Farina M (2001) Amorphous mineral phases in magnetotactic multicellular aggregates. Arch Microbiol 176: 323-328.

10. Posfai M, Buseck PR, Bazylinski DA, Frankel RB (1998) Iron sulfides from magnetotactic bacteria: structure, composition, and phase transitions. Am Mineralog 83: 1469-1481

11. Pósfai M, Buseck PR, Bazylinski DA, Frankel RB (1998) Reaction sequence of iron sulfide minerals in bacteria and their use as biomarkers. Science 280 880-883

12. Posfai M, Cziner K, Marton E, Marton P, Buseck PR, et al. (2001) Crystal-size distributions and possible biogenic origin of Fe sulfides. Eur J Mineral 13: 691-703.

13. Stolz J, Chang SBR, Kirschvink JL (1986) Magnetotactic bacteria and singledomain magnetite in hemipelagic sediments. Nature 32: 849-851.

14. Schüler D (2008) Genetics and cell biology of magnetosome formation in magnetotactic bacteria. FEMS Microbiol Rev 32: 654-672.

15. Postec A, Tapia N, Bernadac A, Joseph M, Davidson S (2012) Magnetotactic bacteria in microcosms originating from the French Mediterranean Coast subjected to oil industry activities. Microb Ecol 63: 1-11.

16. Yan L, Zhang S, Chen P, Liu H, Yin H, et al. (2012) Magnetotactic bacteria, magnetosomes and their application. Microbiol Res 167: 507-519.

17. Bazylinski DA, Williams TJ (2007) Ecophysiology of magnetotactic bacteria Springer 11: 37-75.

18. Faivre D, Schüler D (2008) Magnetotactic bacteria and magnetosomes. Chem Rev 108: 4875-4898.

19. Spring S, Amann R, Ludwig W, Schleifer KH, Schüler D, et al. (1994) Phylogenetic analysis of uncultured magnetotactic bacteria from the alphasubclass of Proteobacteria. Syst Appl Microbiol 17: 501-508.

20. Spring S, Amann R, Ludwig W, Schleifer KH, van Gemerden H, et al. (1993) Dominating role of an unusual magnetotactic bacterium in the microaerobic zone of a freshwater sediment. Appl Environ Microbiol 59: 2397-2403.
21. Blakemore RP (1982) Magnetotactic bacteria. Annu Rev Microbiol 36: 217-238.

22. Flies CB, Jonkers HM, de Beer D, Bosselmann K, Bottcher ME, et al. (2005) Diversity and vertical distribution of magnetotactic bacteria along chemical gradients in freshwater microcosms. FEMS Microbiol Ecol 52: 185-195.

23. Frankel RB, Bazylinski DA, Johnson MS, Taylor BL (1997) Magneto-aerotaxis in marine coccoid bacteria. Biophys J 73: 994-1000.

24. Amann R, Peplies J, Schüler D (2007) Diversity and taxonomy of magnetotactic bacteria. In Schüler D, Magnetoreception and magnetosomes in bacteria. Springer, Berlin, Germany.

25. Kolinko S, Jogler C, Katzmann E, Wanner G, Peplies J, et al. (2012) Singlecell analysis reveals a novel uncultivated magnetotactic bacterium within the candidate division OP3. Environ Microbiol 14: 1709-1721.

26. Lefèvre CT, Viloria N, Schmidt ML, Pósfai M, Frankel RB, et al. (2012) Novel magnetite-producing magnetotactic bacteria belonging to the Gammaproteobacteria. ISME J 6: 440-450.

27. Abreu F, Martins JL, Silveira TS, Keim CN, de Barros HGPL (2007) "Candidatus Magnetoglobus multicellularis," a multicellular, magnetotactic prokaryote from a hypersaline environment. Int J Syst Evol Microbiol 57: 1318-1322.

28. Thorhhill RH, Grant Burgess J, Sakaguchi T, Matsunaga T (1994) A morphological classification of bacteria containing bullet-shaped magnetic particles. FEMS Microbiol Lett 115: 169-176.

29. Vali H, Förster O, Amarantidis G, Petersen N (1987) Magnetotactic bacteria and their magnetofossils in sediments. Earth Planet Sci Lett 86: 389-400.

30. Spring S, Amann R, Ludwig W, Schleifer KH, Petersen N (1992) Phylogenetic diversity and identification of nonculturable magnetotactic bacteria. Syst App Microbiol 15: 116-122.

31. Schuler D (2000) Characterization of the magnetosome membrane in Magnetospirillum gryphiswaldense. In Baeuerlein E, Biomineralization, Wiley$\mathrm{VCH}$, Weinheim

32. Schüler D1 (1999) Formation of magnetosomes in magnetotactic bacteria. J Mol Microbiol Biotechnol 1: 79-86.

33. Simmons SL, Sievert SM, Frankel RB, Bazylinski DA, Edwards KJ (2004) Spatiotemporal distribution of marine magnetotactic bacteria in a seasonally stratified coastal salt pond. Appl Environ Microbiol 70: 6230-6239.

34. Farina M, Esquivel D, Debarros HGP (1990) Magnetic iron-sulfur crystals from a magnetotactic microorganism. Nature 343: 256-258.

35. Mann S, Sparks NCH, Frankel RB, Bazylinski DA, Jannasch HW (1990) Biomineralisation of ferrimagnetic greigite (Fe3S4) and iron pyrite (FeS2) in a magnetotactic bacterium. Nature 343: 258-261.

36. Pan H, Zhu K, Song T, Yu-Zhang K, Lefèvre C, et al. (2008) Characterization of a homogeneous taxonomic group of marine magnetotactic cocci within a low tide zone in the China Sea. Environ Microbiol 10: 1158-1164.

37. Zhu K, Pan H, Li J, Yu-Zhang K, Zhang SD, et al. (2010) Isolation and characterization of a marine magnetotactic spirillum axenic culture $\mathrm{QH}-2$ from an intertidal zone of the China Sea. Res Microbiol 161: 276-283.

38. Blakemore RP, Maratea D, Wolfe RS (1979) Isolation and pure culture of a freshwater magnetic spirillum in chemically defined medium. J Bacteriol 140 720-729.

39. Schuler D, Kohler M (1992) The isolation of a new magnetic spirillum. Zentralb Mikrobiol 147: 150-151.

40. Schleifer KH, Schüler D, Spring S, Weizenegger M, Amann R (1991) The genus Magnetospirillum gen. Syst Appl Microbiol 14: 379-385

41. Matsunaga T, Sakaguchi T, Tadokoro F (1991) Magnetite formation by magnetic bacterium capable of growing aerobically. Appl Microbiol Biotechnol 35: $651-655$

42. Matsunaga T, Okamura $Y$, Fukuda $Y$, Wahyudi AT, Murase $Y$, et al. (2005) Complete genome sequence of the facultative anaerobic magnetotactic bacterium Magnetospirillum sp. strain AMB-1. DNA Res 12: 157-166.

43. Matsunaga T, Tadokoro F, Nakamura N (1990) Mass culture of Magnetic Bacteria and their application to flow type immunoassays. IEEE Trans magn 26: $1557-1559$.

44. Bazylinski DA, Frankel RB, Jannasch HW (1988) Anaerobic magnetite production by a marine, magnetotactic bacterium. Nature 334: 518-519. 
Citation: Prabhu NN, Kowshik M (2016) Techniques for the Isolation of Magnetotactic Bacteria. J Microb Biochem Technol 8: 188-194. doi: 10.4172/1948-5948.1000284

45. Meldrum FC, Mann S, Heywood BR, Frankel RB, Bazylinski DA (1993) Electron microscopy study of magnetosomes in two cultured vibrioid magnetotactic bacteria. Proc R Soc Lond B Biol Sci 251: 237-242.

46. Meldrum FC, Mann S, Heywood BR, Frankel RB, Bazylinski DA (1993) Electron microscopy study of magnetosomes in a cultured coccoid magnetotactic bacterium. Proc R Soc Lond B Biol Sci 251: 231-236.

47. Wenbing L, Longjiang Y, Pengpeng Z, Min Z (2007) Isolation of magnetotactic bacterium WM-1 from freshwater sediment and phylogenetic characterization. Arch Microbiol 188: 97-102.

48. Sakaguchi T, Tsujimura N, Matsunaga T (1996) A novel method for isolation of magnetic bacteria without magnetic collection using magnetotaxis. $\mathrm{J}$ of Microbiol Methods 26: 139-145.

49. Sakaguchi T, Arakaki A, Matsunaga T (2002) Desulfovibrio magneticus sp nov., a novel sulfate-reducing bacterium that produces intracellular single-domainsized magnetite particles. Int J Syst Evol Microbiol 52: 215-221.

50. Delong EF, Frankel RB, Bazylinski DA (1993) Multiple evolutionary origins of magnetotaxis in bacteria. Science 259: 803-806.

51. Simmons SL, Bazylinski DA, Edwards KJ (2006) South-seeking magnetotactic bacteria in the Northern Hemisphere. Science 311: 371-374.

52. Flies CB, Peplies J, Schüler D (2005) Combined approach for characterization of uncultivated magnetotactic bacteria from various aquatic environments. Appl Environ Microbiol 71: 2723-2731.

53. Lefèvre CT, Frankel RB, Pósfai M, Prozorov T, Bazylinski DA (2011) Isolation of obligately alkaliphilic magnetotactic bacteria from extremely alkaline environments. Environ Microbiol 13: 2342-2350.

54. Petermann H, Bleil U (1993). Detection of live magnetotactic bacteria in South Atlantic deep-sea sediments. Earth Planet Sci Lett 117: 223-228.

55. Lefèvre CT, Abreu F, Schmidt ML, Lins U, Frankel RB, et al. (2010) Moderately thermophilic magnetotactic bacteria from hot springs in Nevada. Appl Environ Microbiol 76: 3740-3743.

56. Gao J, Xie J-P, Ding J-N, Kang J, Cheng H-N (2006) Extraction and purification of magnetic nanoparticles from strain of Leptospirillum ferriphilum Trans. Nonferrous Met. 16: 1417-1420.

57. Bazylinski DA, Lefèvre CT (2013) Magnetotactic bacteria from extreme environments. Life (Basel) 3: 295-307.

58. Moench TT, Konetzka WA (1978) A novel method for the isolation and study of a magnetotactic bacterium. Arch Microbiol 119: 203-212.

59. Lefèvre CT, Bernadac A, Yu-Zhang K, Pradel N, Wu LF (2009) Isolation and characterization of a magnetotactic bacterial culture from the Mediterranean Sea. Environ Microbiol 11: 1646-1657.

60. Wolfe RS, Thauer RK, Pfennig N (1987) A "capillary racetrack" method for isolation of magnetotactic bacteria. FEMS Microbiol Lett 45: 31-35.

61. Adamkiewicz VM, Authier A, Dumont S, Garzon S, Leduc S (1991) A simple procedure for enriching and cultivating magnetic bacteria in low agar-mud medium. J of Microbiol methods 13: 255-258.
62. Gao J, Pan h, Yue H, Song T, Zhao Y, et al. (2006) Isolation and biologica characteristics of aerobic marine magnetotactic bacterium YSC- $1^{*}$. Chin J of Ocean and Limn 24: 358-363.

63. Sharma GP, Balomajumder C (2011) Preliminary isolation report of aerobic magnetotactic bacteria in a modified nutrient medium. Recent Res Sci Technol 3: 71-75.

64. Yang CD, Takeyama H, Tanaka T, Matsunaga T (2001) Effects of growth medium composition, iron sources and atmospheric oxygen concentrations on production of luciferase-bacterial magnetic particle complex by a recombinant Magnetospirillum AMB. Enzyme Microb Technol 29: 13-19.

65. Jogler C, Schuler D (2006) Genetic analysis of magnetosome biomineralization Micro Monogr 3: 133-161.

66. Arakaki A, Nakazawa H, Nemoto M, Mori T, Matsunaga T (2008) Formation of magnetite by bacteria and its application. J R Soc Interface 5: 977-999.

67. Matsunaga T, Togo H, Kikuchi T, Tanaka T (2000) Production of luciferasemagnetic particle complex by recombinant Magnetospirillum sp. AMB-1. Biotechnol Bioeng 70: 704-709.

68. Lin W, Tian L, Li J, Pan Y (2008) Does capillary racetrack-based enrichment reflect the diversity of uncultivated magnetotactic cocci in environmental samples? FEMS Microbiol Lett 279: 202-206.

69. Lin W, Li J, Schüler D, Jogler C, Pan Y (2009) Diversity analysis of magnetotactic bacteria in Lake Miyun, northern China, by restriction fragment length polymorphism. Syst Appl Microbiol 32: 342-350.

70. Matsunaga T, Kamiya S (1987) Use of magnetic particles isolated from magnetotactic bacteria for enzyme immobilization. Appl Microbiol Biotechnol 26: 328-332.

71. Xiao Z, Lian B, Chen J, Henry Teng H (2007) Design and application of the method for isolating magnetotactic bacteria. Chin J Geochem 26: 252-258.

72. Farzan F, Shojaosadati SA, Tehrani HA (2010) A preliminary report on the isolation and identification of magnetotactic bacteria from Iran environment. Iranian J Biotechnol 8: 98-102.

73. Chavadar MS, Bajekal SS (2009) Magnetotactic bacteria from Lonar Lake. Curr Sci 96: 957-959.

74. Kundu S, Kulkarni GR (2010) Enhancement of magnetotactic bacterial yield in a modified MSGM medium without alteration of magnetosomes properties. Indian J Exp Biol 48: 518-523.

75. Tajer-Mohammad-Ghazvini $P$, Kasra-Kermanshahi $R$, Nozad-Golikand A Sadeghizadeh M (2013) A Green chemical technique for the synthesis of magnetic nanoparticles by magnetotactic bacteria. World Acad Sci Eng Technol 7: 674-677.

76. Karande VA, Patil RN, Tiwari AP, Satvekar RK, Raut AV, et al. (2014) The isolation and characterization of magnetotactic bacteria from iron ore soil for synthesis of magnetic nanoparticles as potential use in magnetic hyperthermia. IJPAES 4: 321-327. 